\title{
The Ironic Musical Edge: Using Songs to Present and Question Myths
}

\begin{abstract}
Professors never have enough time to cover everything they would like to teach. If the temptation in literature survey courses is to whittle the reading list down to a few canonical texts, the temptation in culture courses is to reduce "American Culture" or "Canadian Culture" to facts and figures, important dates in history, and so on. This paper argues that ironic songs can efficiently introduce important information about a country's myths and sense of self, while simultaneously questioning those myths. After a discussion of syllabus agonies of choice, the paper discusses irony, then irony in music, before finishing with an examination of The Arrogant Worm's comic song "Canada's Really Big."
\end{abstract}

Keywords: Arrogant Worms; culture course; irony, irony in music, culture and society courses

\section{Ost ironije v glasbi: Uporaba pesmi pri obravnavi in vrednotenju mitov}

\author{
POVZETEK
}

Profesorji nimajo nikoli na voljo dovolj časa, da bi lahko svojim študentom temeljito predstavili vse o snovi, ki jo poučujejo. Če je skušnjava pri književnem predmetu zmanjšati obseg literature na nekaj kanoničnih besedil, je skušnjava pri predmetu o družbi in kulturi zmanjšati obseg ameriške ali kanadske kulture na nekaj dejstev in podatkov, pomembnih datumov iz zgodovine itd. Ta prispevek govori o tem, kako lahko z obravnavo ironične pesmi študentom učinkovito predstavimo pomembne informacije $\mathrm{v}$ zvezi $\mathrm{z}$ miti in identiteto neke dežele ter hkrati te mite postavimo pod vprašaj. Prispevek se začne s kritičnim ovrednotenjem učnega načrta, se nato osredini na koncept ironije, še posebej tiste $\mathrm{v}$ glasbi, in se zaključi z analizo ironične pesmi "Canada’s Really Big“ v izvedbi skupine The Arrogant Worms.

Ključne besede: Arrogant Worms; ironija; ironija v glasbi; predmeti o kulturi in družbi 


\section{The Ironic Musical Edge: Using Songs to Present and Question Myths}

\section{Introduction}

Covering an entire country's culture over a semester or two is impossible. This paper argues that there is a crucial place for ironical and humorous songs in general culture courses. Moreover, songs such as "Canada's Really Big" by The Arrogant Worms encourage in-depth reading, despite the seemingly superficial humour. In this view, irony is not a simple turning away or rejection of action but an intellectual pursuit. To be sure, this critical and questioning edge is key to effective irony in the classroom, for irony's frequently critical edge is what differentiates it from "metaphor, allegory, or even lying" (Hutcheon 1992, 220). The paper consists of four parts. The first part provides a brief overview of the difficulties in teaching survey courses (especially over-simplification); the second part considers irony and students' ability to identify irony, the third part briefly examines irony in music, and the final part provides a close reading of the popular song "Canada's Really Big" in order to show how the song uses irony to repeat and simultaneously to undermine national stories or narratives.

\section{Agony of Choice - What to Include in the Syllabus?}

Any university instructor in charge of a survey course on "Major British Writers" or "The American Literary Tradition" is faced with dilemma after dilemma: what to include? Can a recent Pulitzer or Man Booker Prize winner already be part of a "Literary Tradition" and stand spine to spine with greats of the past? In times of mass immigration, crumbling empires and shifting borders, how do we determine who is a British Writer? As well, putting together even a traditional (old-style) canon-based syllabus means overlooking some great works in favour of others.

In survey culture courses with titles such as "Australian Culture" or "American Culture," this agony of choice is even more acute. If it's difficult to distil a country's literature into a single reading list, it's even more difficult to contain the entire history, social contexts and everything else that goes into culture. In a British Culture course how much time, for example, should we devote to Wales and the other three nations in the British Isles? If we are teaching a course on Canada in an English department, what do we do with French-language culture in Quebec and other provinces? When faced with challenges like these, the temptation is to reduce such large notions as "American Culture" or "Canadian Culture" to a timeline of important dates in history, or to focus on a few key events and figures, stereotypical national characteristics and simplified concepts about need-to-know cultural knowledge.

The weak points of traditional approaches to "cultural studies" in the sense of Landeskunde are many. The pedagogical challenges range from having, as a former English major, to discuss geography and sociology, to serving up stereotypes, to excluding minority groups, to generally regarding the foreign country and culture as a static entity. Indeed, cataloguing these and other challenges is a running theme in Michael Byram's volume Culture and Language Learning in Higher Education (1994). ${ }^{1}$ In one chapter, Edward G. Woods acknowledges that "any syllabus"

I thank Janez Skela for pointing me in the direction of this volume. 
demands "some kind of selection" but adds that such selection "could mean [...] learners are left with a random collection of facts that describe the other culture" (80); similarly, Dieter Kerl observes that courses on British culture tend to consist of "a patchwork of topics chosen completely at random" (7), while Harald Husemann warns against providing mere "piecemeal factual background information" (73). These drips and drabs might provide the illusion of completion or of systematic cultural investigation. In other words, despite the fragmented nature of the course readings and foci, by the end of the course students may feel they have ingested a wholesome totality.

In practical terms, no syllabus can be exhaustive and utterly inclusive. The instructor should therefore be upfront about exclusivity, biases and limitations. And yet, regardless of any professorial hedging or admissions of incompletion, the very fact that a particular set of texts and topics lands on a syllabus gives those privileged topics a prescriptive solidity, at least until the final exam. Students may have the impression that they have "done" Britain or that they know the United States because they have mastered a body of facts and figures (which is not to say that educators should avoid facts and important dates altogether!). One becomes an expert in American culture by knowing about the Boston Tea Party, but not necessarily the new Tea Partiers, by being able to identify names of major authors and historical figures, but not necessarily having read them closely. We teachers can exacerbate this reduction by testing that information through fill-inthe-blank questions of names and dates for revolutions, turning points, key historical figures or, when it comes to music, the titles and words of national anthems.

Though it is easy to disparage learning by heart and promote the mantra of critical and conceptual thinking, even conceptual knowledge about a country can be limiting. Teaching ideas and narratives in addition to must-know dates can present problems of its own. Whereas engineering students may learn to "plug and chug" - that is, to "solve text book problems by plugging a value into an equation and chugging out an answer" (Erwin 2005, n.p.) - in cultural studies courses we may inadvertently encourage the same by focusing on national myths or concepts. In terms of unifying symbols, concepts or mythologies, our students might over-apply archetypal or comprehensive terms such as the "American Dream" into a lens for interpreting any cultural artefact from the United States. In other words, a student can "plug" the broad concept of the American Dream into F. Scott Fitzgerald's The Great Gatsby and chug out an interpretation that, while correct in some aspects, does not show much critical engagement with or close attention to the text.

The Canadian equivalent of the American Dream as a critical framework is undoubtedly "survival." It is common for students and scholars alike to scan every text penned by a Canadian for some trace of surviving, enduring, or somehow getting by. For this, we have Margaret Atwood to thank, namely, her seminal 1972 Survival: A Thematic Guide to Canadian Literature. In that important cultural overview, Atwood allowed herself the "sweeping generalization [...] that every country or culture has a single unifying and informing symbol at its core" and that the "[t]he central symbol for Canada [...] is undoubtedly Survival, la Survivance" (Atwood 2012, 47, 49). Because survival "is a multifaceted and adaptable idea" (Atwood 2012, 48) the thesis can and often eagerly is applied to virtually any text. As Michelle Gadpaille argues, Atwood's thesis has served "as a universalist prescription for a national literature" and this prescription causes "creative misreading of tone and genre in the original text" (Gadpaille 2014, 165). Sometimes readers miss the irony that is inherent already in Atwood's phrase "sweeping generalization." They plug "survival" into texts as varied as Yann Martel's Life of Pi (about an Indian boy on a boat with a tiger), and Michael Ondaatje's The English Paper (very much about an Englishwoman 
trying to survive a plane crash). To put it bluntly, because survival is malleable as a concept, because survival entails struggle and challenges, and because all plots and stories require struggles, Atwood's survival thesis lends itself to almost any Canadian, or to any text at all, for that matter. ${ }^{2}$

The drive or desire to pin down nations easily and comfortably is understandable and perhaps even necessary in the classroom. It is, after all, impossible to question an over-arching mythology or a streamlined sense of a national culture if one does not have a sense of that culture to begin with. Though Homi Bhabha is correct in his oft-quoted observation that the "scraps, patches and rags of daily life must be repeatedly turned into the signs of a coherent national culture" - that is, he is correct in pointing out the constructedness of national culture through "narrative performance" (Bhabha 2004, 209) - as educators we have a duty to present these concepts of coherence, along with national symbols and national myths, as a prelude to questioning them. It is insincere to debunk national myths before having an inkling of what they might be. Playing and reading an ironic national song such as "Canada's Really Big" (as shall be seen in the final section) is a convenient way of intelligently examining commonplaces while furthering reading skills through the very act of seeking out ironical and supplementary meanings and ambiguities.

\section{Irony}

Many discussions of irony begin by commenting on its slipperiness. Wayne Booth begins his monumental $A$ Rhetoric of Irony by acknowledging there "is no agreement among critics about what irony is" (Booth 1974, ix). D.C. Muecke's Irony similarly highlights "the notorious elusiveness of the concept of irony" (1). In the few decades since those two works appeared, irony has become an even more slippery term. Writing in 1992, Linda Hutcheon observes that irony's "field of reference has expanded to include wit, humour, and the comic" (Hutcheon 1992, 219). In Irony's Edge she notes: "One of the misconceptions that theorists of irony always have to contend with is the conflation of irony and humor" (Hutcheon 1994, 5). Though many, perhaps even most, examples of irony involve the humour so often inherent in incongruity, irony is not only funny; and sometimes it is not even that.

If, as C. Hugh Holman writes in A Handbook to Literature, "[ $\mathrm{t}]$ he ability to recognize irony is one of the surest tests of intelligence and sophistication," the world is peopled by intelligent, sophisticated readers of daily life. Today irony is recognized everywhere. In addition to having become a vague synonym for "wit" or "humour," the term "irony" or "ironic" is creatively misused as a synonym for any sort of coincidence or bad luck - perhaps most famously in Alanis Morrissete's 1995 megahit "Ironic," which begins "An old man turned 98; he won a lottery and died the next day." An actuary would see neither irony nor humour nor the unexpected in that nonagenarian's death. As Katherine L. Turner writes, and as the articulate Morrissette surely knows, "coincidences abound, but ironies are few. The flagrant semantic misusage, however, is ironic" (Turner 2015, 2).

Whatever the definition chosen, irony requires a keen and informed reader. For example, when John Lennon poached the title of the 1968 Beatles song "Happiness Is a Warm Gun" from an American Rifleman story, he was recontextualizing it ironically (Davies 2014, 314). The song

In her preface to the 2012 edition, Atwood notes the wild elasticity of the book itself: "The raucous though unlikely success of Survival caused me to morph overnight from a lady poet with peculiar hair to the Wicked Witch of the North, accused of evil communism or bourgeois capitalistic sycophancy, though others greeted me as the long-awaited forger of the uncreated conscience of CanLit" (Atwood 2012, 7). 
is illustrative of irony's notorious slipperiness. The easiest way to explain "happiness is a warm gun" as an instance of irony is to show that in its new context as a pop song the title is not to be taken at face value, whereas in the original pages of the gun magazine a "warm gun" has a happy cosiness to it. Focussing on the music, David Rowley points out that the song's "satire is all the more prickly for being played as a mock-innocent 1950s' four-chord doo-wop" (Rowley 2013, 61). The original Rifleman use refers to a father and son bonding moments while out hunting and that situation thus appears to be the earnest semantic bedrock on which irony dances. However, perhaps matters of interpretation are not quite so clear, for even in a rifle-loving environment, one cannot assume utter sincerity and a complete absence of humour or irony.

The semantic confusion surrounding irony stems also from the many types of literary irony in existence, almost all of which have a "root sense of dissembling or hiding" (Abrams 1988, 91). There is: 1) the situational irony best evinced in the twist endings of an O. Henry or Maupassant story; 2) the dramatic irony that makes the savvy spectator want to warn the stage actor of lurking danger; 3) the tragic irony that led Oedipus to slay his father and lie with his mother; 4) the cosmic irony that exists before we realize, like Gloucester in King Lear, that "As flies to wanton boys are we to th' gods, / They kill us for their sport." This list is not exhaustive, and worthy of mention here are also structural irony, Romantic irony, Socratic irony, the sub- and supra-categories of stable and unstable irony, verbal and non-verbal or situational irony. ${ }^{3}$

Despite irony's many meanings, if my experiences in Slovenian university classrooms can be generalized, almost all students have a crystalized concept of what irony means. To provide an extreme example, when I wrote "Lovely sentence!" on a student's essay, she later asked me "What's wrong with it?" For many, irony is an intelligence test in which the term is a synonym for sarcastic and caustic inversion of what has been said. It that simplistic view irony is merely "a figure of speech in which the actual intent is expressed in words which carry the opposite meaning” (Holman 1972, 279). But this is a limited sense of irony and its potentials.

Viewing irony as a simple flipping of meaning ignores the ludic aspect of irony that allows us to simultaneously say and yet not say something, to critically hold two positions at once. To quote Linda Hutcheon again, perhaps irony is fundamentally a "semantic balancing act, [...] a fencesitting, bet-hedging middle ground where evasion and complicity sit - not totally comfortably - with commitment and critique" (Hutcheon 1992, 219). In other words, irony can be a barrier to decisive action and it is for this reason that Muecke, in his own book-length study, sees the functioning of the world as essentially non-ironic, since the "ordinary business of the world in which most of us are engaged most of the time could not be carried on in a spirit of irony" (Muecke 1972, 2). Can one ironically bake a loaf of bread? Can one ironically purchase the same? If a transaction has taken place, it is difficult to argue that it took place only in a spirit of irony.

If irony is a barrier to decisive action, it also has its own barriers. Wayne Booth notes "five major kinds of crippling handicap" to recognising irony: "Ignorance, Inability to Pay Attention, Prejudices, Lack of practice, and Emotional inadequacy" (Booth 1974, 222). Four of these handicaps are especially present in any classroom, especially in a cross-cultural setting in which students do not share a common referential framework.

1. Ignorance. No reader of texts of any sort will be able to spot all textual irony, and "the more remote a work is from my home province (my century, my country, my family [...])

As will be evident to the reader, this (incomplete) list leans on the irony-focussed works in the bibliography. 
the more mistakes I will make in a given reading period" (Booth 1974, 222f). The aim of the teacher, of course, is to provide or facilitate overcoming of ignorance.

2. Inability to pay attention. The difficulties here are two-fold. First, in the interest of efficacy or due to lack of engagement, we do not pay "full attention to the words that sweep over us daily" (Booth 1974, 223). Students may not be on the lookout for irony in venerable literary texts such as Pope's "Rape of the Lock" or Swift's "A Modest Proposal," to take two of the most obvious, traditional and canonical examples.

3. Prejudice. We all have our own beliefs, and the key to being a mature reader is to "take thought about [these prejudices] as we read" (Booth 1974, 224), also in terms of form and literary expectations. Students, thus, might miss the irony in Swift's "A Modest Proposal" precisely because they expect literature to be earnest - and only earnest - in tone.

4. Lack of Practice. Our sense of irony and our ability to identify ironies of whatever type develop as we age. "To use complicated ironies on children," claims Booth, "is sadistic because even the brightest child lacks the experience [...] that would enable him to interpret irony" (Booth 1974, 226). Along these lines, Joseph O. Milner et al. point out in "The Ironies of Students' Recognition of Irony" the "all-too-common approach [of] giving students no strategies for recognizing irony" $(1999,308)$. Though those authors focus on elementary schools, their observation that young people are "hampered by a literalism" is valid for all ages.

5. Emotional Inadequacy. Sometimes individuals "respond with sentiment to what is intended as a parody of sentiment"; conversely, they "may protect themselves by laughing "ironically' at a great tragic scene" (Booth 1974, 227). Booth is sombre about this fifth type of handicap: "So far as I can see, there is simply nothing one can do about this kind of inadequacy" (Booth 1974, 227). ${ }^{4}$

When reading ironical texts, students have to learn to be careful readers, to be aware of inconsistencies between tone and subject matter. Fortunately, because students are generally more informed about popular modes of music than they are about 18th-century wits, music is a convenient introduction to unravelling irony. As Hutcheon notes, while focusing on the "inclusionary aspect of irony," "young students who can speak the language of irony outside the classroom, who comprehend its subtleties in popular culture, might fail to see it in a text like Swift's ['Modest Proposal']" (221). Students feel less removed from popular songs ${ }^{5}$ than they do from grimly comic ideas about selling Irish babies to English landlords, or violating a bit of hair.

\section{Music and Irony}

Irony depends on specific meanings, which in turn means that any discussion of irony in music runs into the problem of meaning itself in music. Philosopher and composer Roger Scruton speaks of a fundamental split among musicologists: "The dispute is between those who affirm, and those who deny, that music has a meaning other than itself" (Scruton 2009, 4). Scholars are divided as to whether a piece of instrumental music can refer to the world outside or whether each musical score is a completely autonomous world. R. A. Sharpe's formulation in Philosophy of

In the classroom "emotional inadequacy" is complicated by the public nature of reading. The student who laughs at Romeo's death may be employing a defence mechanism (not showing emotions in front of his/her peers) or provoking the educator and others.

5 Of course, because music is so important for identity construction, choosing the right sort of song matters. Hip hop, heavy metal, etc., will no doube attract the attention of a few students, but repel others. 
Music: An Introduction reads: "the most fundamental difference lies between those who think of music as an autonomous, abstract art form, and those who think that it draws its importance for us from connections, no matter how tenuous, with our lives outside the world of music" (Sharpe 2004, 27). Though I hear nature aplenty in Beethoven's Pastoral Symphony, without the prompts on my CD liner notes (Movement 1: "Scene by the brook"; Movement 4: "Thunder") I would not have been predisposed to hearing the rippling water and those claps.

If musicologists disagree on whether there is meaning in music, performers are in agreement that humour, including irony, is indeed possible. Obviously, with the help of gestures (think of the jazz trumpeter hamming it up during a solo, the operatic diva acting like a diva onstage) and with the help of lyrics, music can make us laugh. Pianist Alfred Brendel addresses this matter in A Pianist's A-Z: "Can music be funny, comical, humorous on its own, without the help of the word or the stage? My answer is yes" (Brendel 2013, 35). The problem in not hearing humour in music stems from that fact that "Music has been granted the ability to sigh but not to laugh. Some people deem themselves to be above laughter and consider earnestness a proof of human maturity" (Brendel 2013, 35). The same sober expectations that make us not see the humour in Alexander Pope's "Rape of the Lock" may make us not hear irony or even playfulness in both instrumental music and in music with words.

Katherine L. Turner, paraphrasing the Roman rhetorician Quintilian on verbal irony, says, "[i]n a musical context then, $[\ldots]$ a shift towards irony might be marked by a change in 'the performance, the stylistic character of the music or the nature of the genre,' any of which can serve to elucidate a listener" (Turner 2015, 9). In practical classroom terms, this familiarity means that students who have been brought up in a culture of ubiquitous jazz, rock, classical or hip hop sounds will soon hear when the music doesn't match the verbal message. Because music has invaded the public space (is there such a thing as a quiet café or music-free store today?), we are all more fully aware of musical genres than we are of literary genres. Students, therefore, can often tell when music "is being used ironically" $\left(\right.$ Cook 1998, 5). ${ }^{6}$

Randy Newman is surely the modern master of using music ironically by intentionally mismatching tunes and lyrics. The author of the saucy classic "You Can Leave Your Hat On" wears two hats: he has composed much film music, but he has also excelled as a writer and performer of brutally sardonic, critical lyrical exposés of the excesses of American society, past and present. " "Sail Away," for example, is a perverse turn on the immigration success story; it envisions slaves willingly leaving Africa. In that song, a slave trader travels to Africa to lure slaves to the New World, to sell America by advertising it as a land of milk and honey. "You'll get food to eat," intones the smarmy trader, sweetening the offer with "You'll just sing about Jesus and drink wine all day" before adding to the awful non sequitur: "It's great to be an American."

As Sabatino DiBernardo argues in "God, Flag, and Country: Ironic Variations on a Metaphysical Theme," "Sail Away" and other Newman songs are historical in view but contemporary in scope

The quotation is from musicologist Nicholas Cook's consideration of how musical genres are used in commercials: "you somehow know that the music goes with fast food or financial institutions or whatever the commercial is about - or, if it doesn't, that it is being used ironically" (Cook 1998, 5).The comment that we "somehow know" is tongue-in-cheek; we have been trained through media saturation to make associations between sophistication and classical music or between rebellion and rock.

Victor Kennedy quotes Peter Winkler in his discussion of Newman: "[His] lyrics tend to be simple in vocabulary, terse, and elliptical: what is left unsaid is often more important than what is said. And irony is his most characteristic mode" (Winkler 1988, 2), and adds "this allows the listener to draw his or her own conclusion" (Kennedy 2014, 101). The listener encouraged to be active as an interpreter. 
- "In critiquing the historical horrors of slavery and racism, Newman manages to indict the nation's sales-oriented colonization and commodification of the subject through the marketing of desire" (DiBernardo 2015, 112). To use Booth's term again, emotionally adequate listeners with even a rudimentary grasp of English will be horrified. More horrifying still is that Newman sugar-coats the racist message with a beautiful tune. The music is lovely, and a stranger to English would be hard-pressed to guess the song's content. "The sound of irony here, as in many of Newman's songs, is a dissonant juxtaposition of musical style and lyrical content. Newman composes a pretty song to convey an ugly message via ironic critique” (DiBernardo 2015, 111). The gap between the sweet sounds and the appalling words is uncomfortably large and the song is therefore grotesque.

Indeed, the gap between form and content is so incongruous that one interviewer "questioned [Newman's] motivation for composing such a beautiful song about such a horrid subject" (Courrier 2005, 132). Newman's defence was that simply stating "Slavery is bad" is a truism; "It's just too easy. And it has no effect" (Courrier 2005, 132). A straight-up denigration of slavery would have "no effect" because it would not involve the intellect and critical skills of the listener. The listener would not be drawing his or her own conclusions and would thus not be engaging critically and actively with the text.

\section{Irony in Action: "Canada's Really Big”}

A Canadian comedy band that undercuts national myths and stories is "The Arrogant Worms," whose very name indicates a refreshing levity in the gravely serious world of so much popular music. As they proclaim on their website, they "provide tuneful and silly escapism for everyone who needs it," including teachers and students. With catchy tunes that frequently riff on songs we may know, there is an air of Eurovision, but with the important difference that The Worms' lyrics and clever, irony-laden and thus rife for the classroom. Their songs include "Carrot Juice Is Murder," "I Am Cow" ("I am cow, hear me moo, / I weigh twice as much as you, / and I look good on the barbecue"), and "History Is Made by Stupid People" ("Scott became famous for freezing to death in Antarctica. / Columbus made history thinking some island was India"). "Me Like Hockey," meanwhile, is a syntax-poor ode to Canada's national winter sport: "Favourite night is Saturday night / 'Cause me can watch hockey fights." The song ironically points out that Canada's imagined community is based on a troglodyte thirst for mediated violence.

The typical Arrogant Worms song is replete with references to well-known and not-so-wellknown Canadians (such as hockey great Wayne Gretzky and folk singer Rita MacNeil) and Canadian details. Their songs are useful for the classroom as a way of introducing basic facts and stories about Canada. More importantly, concepts of national identity are required if the listeners wants to grasp the humour and irony in an Arrogant Worms song; still more importantly, their songs question myths of essentialist Canadian politeness and peacefulness.

In the spoken introduction to "Canada's Really Big," on the 1997 Live Bait album, they proclaim "We are very patriotic Canadians" and will therefore sing "our national anthem... that we wrote." They therefore poke fun at the arbitrariness of national anthems, that is, at a type of song that becomes "naturalised" only through repetition and through having an official stamp of approval. Their unofficial national anthem is not played on special occasions; rather, it is a joyous quotidian affirming and questioning of patriotism. ${ }^{8}$

On the matter of school- and state-sanctioned patriotism, see David G. Hebert and Alexandra Kertz-Welzel's volume 
The song itself begins in a mode of nostalgic lament for a country of yore that no longer exists:

When I look around me, I can't believe what I see

It seems as if this country has lost its will to live

The cliché "I can't believe what I see" slides into the farcical personifying of "this country," which is invested with subjective willpower. Individuals can lose the "will to live," but a political abstract cannot. The humour resides in the purported uniqueness of having lost something it can't have had in the first place - after all, no country can lose a will to live. In this comic turn on a traditional motif, agency and individuals are all but ignored. The state is to blame.

The singer then professes "The economy is lousy, / We barely have an army," neither of which will make much sense to a room full of Slovenians. Rather, the lines only acquire meaning measured against the far larger American economy and military might. In the classroom, pointing out the constant Canadian use of the United States as a limiting international mirror is useful. ${ }^{9}$

After the lamenting, the singer finds absurd nationalist solace: "But we can still stand proudly 'Cause Canada's really big." Whereas the comedy of the lines referring obliquely to the United States will not necessarily be obvious to all students, this bragging about size is doubly absurd. First, there is the humour of loudly pronouncing a well-known fact as if it were new information; second, there is the absurdity of bragging to a primarily Canadian audience - since most Arrogant Worms fans are Canadian ${ }^{10}$ - about the one fact everybody knows about Canada. They blare out "the second largest country" with a pretend political naivety; other countries are mentioned, but only to prove, with exquisite circularity, that Canada is big: "Most people will tell you that France is pretty large / But you can put fourteen France's into this land of ours" and, for the sake of an awful internal rhyme: "We're larger than Malaysia, almost as big as Asia."

In sublimely mock-heroic mode, the Worms compare Canada to Russia in geographical but also political terms:

We're the second largest country on this planet earth

And if Russia keeps on shrinking, then soon we'll be first.

At first sight, the juxtaposition seems to depict Canada as a relatively stable country in comparison to "shrinking" Russia, which here seems to stand for the former Soviet Union. Thus, there is a clear nationalistic complacency as Canada is once again painted as a place of "peace, order and good government" (to quote from Canada's Constitution Act of 1867). However, the confident prediction of "soon we'll be first" is immediately followed by the parenthetical caveat "(As long as we keep Quebec)," undermining the previous allusion to stability. Given that Live Bait was released just two years after the 1995 Quebec Referendum, narrowly won by the federalist side, fragility is the ironic message being sent. Whereas the conditional in "if Russia keeps on

Patriotism and Nationalism in Music Education, especially Simon Keller's nuanced "Foreword: On Patriotism and Education" (Keller 2012: xiii-xviii).

$9 \quad$ Two pithy but telling examples: when a former Canadian Prime Minister proclaimed that coalition governments are somehow "undemocratic," there was little public outcry ("Stephen Harper's Curious Attack"); similarly, Canadians have been slow to see the merits of proportional, as opposed to first-past-the-post, voting ("Canada Can Do Better"). Though coalition government and proportional voting are the norm in many countries, they are not the norm in the United States, Canada's go-to reference point.

10 In my case it was a Slovenian student that introduced me to the Arrogant Worms. 
shrinking" seemed a possibility, the potential break-up of Canada is, by juxtaposition, linked to another large country's difficulties.

More significant in this passage is the literal bracketing ${ }^{11}$ of a key political concern in Canada: political independence of Quebec. In a song that is ostensibly about unity, division occurs. But there is a further division in the song, namely, between dominating subject and passive object. Quebec is literally objectified because the province is in what grammar teachers used to call the "objective case": "as long as we keep Quebec." Whereas "we" in national anthems generally purports to encompass all within a particular nation, in this English-language song Quebec is made doubly voiceless: the self-proclaimed "national anthem" is in English. It therefore ignores the approximately the one-fifth of Canadians whose mother tongue is French. Also, the song foregrounds Quebec as a territory to be owned or kept by a larger political entity (Canada) of which it is somehow a part yet not a part.

"Canada’s Really Big" is preceded by many popular or folksy songs alluding to and praising the geography and the vastness of Canada. Two standard songs are Stan Rogers's "Northwest Passage" (which sings of "A land so wide and savage") and, on the French-language side, Gilles Vigneault's "Mon pays" ("Mon pays, ce n'est pay un pays, c'est l'hiver / Mon jardin ce n'est pas un jardin, c'est la plaine"). ${ }^{12}$ As Patricia Cormack and James Cosgrave write in Desiring Canada: CBC Contests, Hockey Violence and Other Stately Pleasures, the "Arrogant Worms cleverly point out" that Canada exists solely "by virtue of taking up space" (Cormack and Cosgrave 2013, 54). The song may sound bombastic and jingoistic, but it maintains a self-deprecating and simultaneously critical stance to be playfully examined by the listener to this ironic tune.

\section{Conclusion}

Through songs such as "Canada's Really Big," the instructor can invite students to learn about national self-images while also encouraging critical reading skills by making students listen closely for markers of irony and thus expanding understanding. They simultaneously learn the traditional basics about a country (in this case, the size of Canada, the traditional and oftespoused love of "peace and order," among other facts and mythologies alluded to in the song). By identifying irony and putting its critical edge to use, critical songs do not reduce states to "a random collection of facts" and the lessons are not limited to providing "piecemeal factual background information." Well-chosen songs that illustrate yet also challenge national myths of greatness are therefore an ideally efficient manner of challenging pedagogical tendencies to simplistic views of nations. Irony and examination of the same is, in this case, not the opposite of action but the epitome of intellectual endeavour.

\section{References}

Abrams, M. H. 1988. A Glossary of Literary Terms. 5th ed. Fort Worth, etc.: Holt, Rinehart and Winston.

Arrogant Worms. 1997. “Canada’s Really Big.” Live Bait. Arrogant Worms Records.

Atwood, Margaret. 2012 (1972). Survival: A Thematic Guide to Canadian Literature. Toronto: Anansi.

\footnotetext{
11 While the listener cannot see the parenthesis without the lyrics in front of them, the singer clearly indicates the Quebec-caveat through tone. The line "as long we keep Quebec" sounds like a whispered musical aside.

12 In language that clearly shows the exclusionary aspects of some nationalistic songs (or songs that are read nationalistically), I. S. MacLaren argues "Northwest Passage" "is, at least for white, southern, English-speaking Canadian males [...] perhaps as inspiring as Gilles Vigneault’s song, 'Mon Pays' (1964), became for nationalist Québecois in the 1960s” (MacLaren 1996, n.p.).
} 
Bhabha, Homi K. 2004 (1994). The Location of Culture. Abingdon: Routledge.

Booth, Wayne C. A. 1974. Rhetoric of Irony. Chicago: The University of Chicago Press.

Brendel, Alfred. 2013. A Pianist's A-Z: A Piano Lover's Reader. London: Faber and Faber.

Byram, Michael. 1997. Teaching and Assessing Intercultural Communicative. Clevedon: Multilingual Matters.

Byram, Michael, ed. 1994. Culture and Language Learning in Higher Education. Clevedon: Multilingual Matters.

Cook, Nicholas. 1998. Music: A Very Short Introduction. Oxford: Oxford University Press.

Cormack, Patricia, and James Cosgrave. 2013. Desiring Canada: CBC Contests, Hockey Violence, and Other Stately Pleasures. Toronto: University of Toronto Press.

Courrier, Kevin. 2005. Randy Newman's American Dreams. Toronto: ECW Press.

Davies, Hunter. 2014. The Beatles Lyrics: The Stories Behind the Music, Including the Handwritten Drafts of More Than 100 Classic Beatles Songs. New York, Boston, London: Little, Brown and Company.

DiBernardo, Sabatino. “God, Flag, and Country: Ironic Variations on a Metaphysical Theme.” In This Is the Sound of Irony: Music, Politics and Popular Culture, edited by Katherine L. Turner, 103-16. Burlington, VT: Ashgate.

Erwin, Gary J. August 4 2004. "No More 'Plug and Chug.” Accessed January 15, 2016. https://my.kettering. edu/news/no-more-plug-and-chug

Gadpaille, Michelle. 2014. "Thematics and its Aftermath: A Meditation on Atwood's Survival." Primerjalna književnost 37 (3): 165-77.

Hebert, David G., and Alexandra Kertz-Welzel. 2012. Patriotism and Nationalism in Music Education. Farnham, UK, and Burlington, VT: Ashgate.

Holman, C. Hugh. 1972. A Handbook to Literature. Indianapolis: Odyssey.

Husemann, Harald. 1994. "From NIMBY Landeskunde to IMBY Cultural Studies." In Culture and Language Learning in Higher Education, edited by Michael Byram, 73-78. Clevedon: Multilingual Matters.

Hutcheon, Linda. 1992. "The Complex Functions of Irony." Revista Canadiense de Estudios Hispánicos 16 (2): 219-34.

—. 2005 (1994). Irony's Edge: The Theory and Politics of Irony. Abingdon: Routledge.

Keller, Simon. 2012. “Foreword: On Patriotism and Education.” In Patriotism and Nationalism in Music Education, edited by David G. Hebert and Alexandra Kertz-Welzel, xiii-xviii. Farnham, UK, and Burlington, VT: Ashgate.

Kennedy, Victor. 2014. “Aspects of Evil in Traditional Murder Ballads.” Elope 11 (1): 93-109. doi: 10.4312/ elope.11.1.93-109

Kerl, Dieter. 1994. "The Case of Landeskunde: A Vicious Circle?” In Culture and Language Learning in Higher Education, edited by Michael Byram, 5-9. Clevedon: Multilingual Matters.

MacLaren, I. S. 1996. "Tracing One Discontinuous Line through the Poetry of the Northwest Passage." Canadian Poetry. 39: 7-48. Accessed online: http://www.canadianpoetry.ca/cpjrn/vol39/tracing_one_ discontinuous_line.htm

Milner, Joseph O. et al. 1999. “The Ironies of Students' Recognition of Irony.” The Clearing House 72 (5): 308-14. doi:10.1080/00098659909599415.

Muecke, D. C. 1970. Irony. Critical Idiom. New York: Methuen and Co.

Newman, Randy. 1972. “Sail Away." Sail Away. Reprise. 
Rowley, David. 2013. All Together Now: The abc of the Beatles Songs and Albums. Leicestershire: Matador.

Scruton, Roger. 2009. Understanding Music. London: Continuum.

Sharpe, R.A. 2004. Philosophy of Music: An Introduction. Montreal: McGill-Queen's.

Turner, Katherine L. 2015. "Introduction: The Sound of Irony/The Irony of Sound.” In This Is the Sound of Irony: Music, Politics and Popular Culture, edited by Katherine L. Turner, 1-15. Farnham, UK, and Burlington, VT: Ashgate.

—, ed. 2015. This Is the Sound of Irony: Music, Politics and Popular Culture. Farnham, UK, and Burlington, VT: Ashgate.

Winkler, Peter. 1988. "Randy Newman's Americana." Popular Music 7 (1): 1-26. doi:10.1017/ S026114300000249.

Woods, E.G. 1994. "British Studies in English Language Teaching." In Culture and Language Learning in Higher Education, edited by Michael Byram, 79-90. Clevedon: Multilingual Matters. 